\title{
Inclusion of cottonseed meal into loose mineral mix supplements increases the voluntary intake of the supplement by grazing heifers
}

\author{
R. M. Dixon A, C, A. Anderson ${ }^{\mathrm{B}}$ and J. C. Petherick ${ }^{\mathrm{A}}$ \\ ${ }^{A}$ Queensland Alliance for Agriculture and Food Innovation (QAAFI), Centre for Animal Science, The University of \\ Queensland, PO Box 6014, Rockhampton, Qld 4702, Australia. \\ ${ }^{B}$ Queensland Department of Agriculture and Fisheries, Spyglass Beef Research Facility, MS 99, Charters Towers, \\ Qld 4820, Australia. \\ ${ }^{\mathrm{C} C}$ Corresponding author. Email: r.dixon77@uq.edu.au
}

\begin{abstract}
Loose mineral mix (LMM) supplements based on ingredients such as salt, urea and minerals offered ad libitum are widely used to provide additional nutrients to grazing cattle, but it is often difficult to achieve target intakes. An experiment with heifers grazing mature tropical pasture examined the effects of substituting $80,160 \mathrm{or} 320 \mathrm{~g} / \mathrm{kg}$ of the salt in a LMM supplement with cottonseed meal on the voluntary intake of the LMM supplements by paddock groups of heifers over 10 weeks. Average voluntary intake of a LMM containing $(\mathrm{g} / \mathrm{kg}) 640$ salt, 300 urea and 60 ammonium sulfate ( $40.2 \mathrm{~g}$ DM and $6.14 \mathrm{~g}$ total nitrogen/day) was increased linearly $(P<0.001)$ to $50.8 \mathrm{~g}$ DM and $8.88 \mathrm{~g}$ total nitrogen/ day when up to $320 \mathrm{~g} / \mathrm{kg}$ cottonseed meal was substituted for salt in the LMM. This increase in intake of nitrogen in LMM was due to the increase in voluntary intake of the supplement rather than the increased nitrogen concentration of supplement. The distribution of daily intake of supplement within paddock groups of heifers was estimated during Weeks 5 and 10 using supplements labelled with lithium sulfate. Neither the coefficient of variation within paddock groups of heifers in supplement intake (mean 96\%), nor the proportion of non-consumers of supplement (mean 17\%), was changed $(P>0.05)$ by substitution of salt with cottonseed meal. In conclusion, the inclusion of a palatable protein meal into LMM increased the voluntary intake of this type of supplement.
\end{abstract}

Additional keywords: cattle, lithium marker, palatability, supplement intake, variability in intake.

Received 3 September 2014, accepted 29 October 2015, published online 22 March 2016

\section{Introduction}

Production of grazing ruminants is often constrained by low concentrations of essential nutrients in pastures. In seasonally dry tropical rangelands, such as in Australia, the Americas and Africa, pastures are often deficient in nitrogen $(\mathrm{N})$ during the dry season, and in minerals such as phosphorus, sulfur and sodium during the wet season (Little 1982; Winks 1984; McDowell 1996). Loose mineral mix (LMM) supplements containing ingredients such as salt, urea, calcium phosphate and other minerals are widely used to deliver non-protein $\mathrm{N}$ and minerals to ruminants grazing in extensive rangelands. However, in regions where ruminants do not have a strong intrinsic attraction to salt, voluntary intakes of LMM are often insufficient to provide the amounts of supplementary nutrients needed by grazing ruminants to meet their expected nutritional requirements. Farm managers usually have to depend primarily on regional experience to choose LMM supplements which achieve appropriate supply of supplementary nutrients.

In animals with experience of supplements, the voluntary intake of a LMM supplement is likely to be determined by a combination of its palatability relative to pasture (Heady 1964; Pamp et al. 1976) and by post-ingestive feedback mechanisms, which may be positive or negative (Provenza 1995, 1996; Arsenos and Kyriazakis 1999; Dixon et al. 2003b). However, because most feedstuffs potentially cause post-ingestive feedback responses it is often difficult to conclude whether a change in voluntary intake of LMM supplement is due to a change in the intrinsic attractiveness of the supplement, to post-ingestive feedback mechanisms, or a combination of these effects. To improve the management options to deliver target intakes of supplementary nutrients in a LMM to grazing cattle a better understanding of the factors influencing voluntary intakes of LMM supplements is needed. Inclusion into LMM of feedstuffs such as protein meals, grain or molasses has been reported to increase voluntary intake of LMM supplements (McDowell 1996; Dixon 1998). Further considerations for the efficacy and cost-effectiveness of LMM supplement delivery systems are that there is usually wide variation in voluntary intake of such supplements among individuals in a herd, and a substantial proportion of a herd may not consume any supplement (Dixon et al. 2000, 2001). The present experiment examined the effect of varying the proportions of cottonseed meal in LMM supplements on the voluntary intake and distribution of intake of supplement by heifers. 


\section{Materials and methods}

The experiment was carried out at the Swan's Lagoon Research Station situated $100 \mathrm{~km}$ SSE of Townsville in the summerrainfall, seasonally dry, tropics of northern Australia. The annual cycles of pasture and cattle growth at this site have been described by Winks (1984). The pastures comprised tropical grasses native or naturalised to the open eucalyptus woodlands of the speargrass (Heterpogon spp.) pasture region of coastal north-eastern Australia.

The Bos indicus $\times$ Bos taurus heifers used in the experiment were from the research station herd, and were generally of docile temperament and accustomed to mustering and handling. The heifers $(n=120)$ were initially $8-10$ months of age, liveweight $(\mathrm{LW})$ mean 171 (s.d. $=13) \mathrm{kg}$ and body condition score mean 5.1 (s.d. $=0.32$ ) (on a 9-point scale; National Research Council 1996), and were allocated by stratified randomisation based on LW to 12 groups. These groups (each $n=10$ ) were then allocated to 1215 -ha paddocks of native pasture in a completely randomised design. The pasture available was senesced and was visually estimated to exceed 2 t DM/ha. Four supplementation treatments were imposed. For 10 weeks during the late dry season (25 September-6 December 1994) the heifers were offered ad libitum one of four types of LMM supplements. LMM-1 consisted of ( $\mathrm{g} / \mathrm{kg}$ air-dry) 640 salt (sodium chloride), 300 urea and 60 ammonium sulfate. For the LMM-2, LMM-3 and LMM-4 supplements 80,160 and $320 \mathrm{~g} / \mathrm{kg}$, respectively, of the salt in LMM-1 was replaced with the same amount of solvent-extracted cottonseed meal. Supplements LMM-1 to LMM-4 contained 153, 158, 164 and $175 \mathrm{~g}$ total N/kg DM, respectively, and each contained $153 \mathrm{~g}$ non-protein $\mathrm{N}$ from urea and ammonium sulfate. Supplements were offered in a 2.4-m trough near the water trough in each paddock. Fresh LMM supplements were offered twice weekly, and on each occasion the residues were removed, weighed and subsampled for DM content; these data were used to calculate the voluntary intake of supplement DM on a weekly basis by each of the paddock groups of heifers.

Following the procedures described by Suharyono (1992) and Dixon et al. (2003a) lithium was used as a marker on two occasions to estimate the distribution of ingested supplement among individual heifers in each paddock group. Lithiumlabelled LMM supplements were prepared by mixing lithium sulfate monohydrate (6-12 g lithium/kg supplement) with the ingredients during preparation; the amount of lithium sulfate added was intended to provide $\sim 1.5 \mathrm{mg}$ lithium $/ \mathrm{kg}$ LW. Lithium-labelled supplement was offered between 0700 hours and 1630 hours on 1 day during Weeks 5 and 10; on the following day the heifers were mustered commencing at 0700 hours and before access to water, weighed, and then blood sampled from the jugular vein using vacutainers containing potassium EDTA as an anti-coagulant. Samples were immediately chilled in iced water, centrifuged (3000 $g$ for $10 \mathrm{~min}$ at room temperature) to separate plasma and the plasma was stored frozen.

Dry matter content of supplements offered and refused was determined by oven drying at $70^{\circ} \mathrm{C}$. Plasma proteins were precipitated by addition of $1 \mathrm{~mL}$ plasma to $5 \mathrm{~mL} 2 \%$ trichloroacetic acid and the supernatant was separated by centrifugation $(3000 \mathrm{~g}$ for $10 \mathrm{~min}$ at room temperature).
Lithium concentration in the supernatant was determined using an inductively coupled plasma mass spectrometer. Net concentrations of lithium in plasma were calculated by subtraction of background lithium concentrations in plasma obtained from representative animals before lithium-labelled supplements were offered. The net concentrations of lithium in plasma, the LW of the individual heifers, and the total intake of lithium-labelled supplement by each paddock group, were used to calculate the distribution of supplement intakes among the heifers in each paddock on the day on which the lithiumlabelled supplement was fed. Non-consumer animals were defined as those consuming less than $1 \mathrm{~g}$ of lithium-labelled supplement during the interval during which it was provided (Dixon et al. 2003a).

A repeated-measures ANOVA was used to examine the interaction between time (i.e. week of supplementation) and the LMM treatment on voluntary intake of supplement. The paddock group was considered as the experimental unit and thus there were three replications per treatment. The differences in the mean voluntary intake of supplement (g DM/day and g N/day), averaged over the 10-week period, between the four types of LMM supplement treatments were investigated using ANOVA. Where the $F$-test was significant $(P<0.05)$, pair-wise comparisons between treatment means were made using the least significant difference (1.s.d.) test. Linear regression was used to examine the significance of the relationship between the average voluntary intake of supplement as $\mathrm{g} \mathrm{DM} /$ day and $\mathrm{g} \mathrm{N} / \mathrm{day}$, and the increasing proportion of cottonseed meal in the LMM supplement.

The coefficient of variation (CV) of supplement DM intake and the proportion of non-consumers of supplement DM were calculated from the individual animal data within paddock groups for each treatment and replicate group combination for both Weeks 5 and 10, and were then analysed for treatment differences using ANOVA. Also the relationships between the $\mathrm{CV}$ of supplement intake, or the proportion of non-consumers of the supplement, with the amount of voluntary intake of supplement were investigated for each of Week 5 and Week 10 using linear regression.

\section{Results}

The heifers were in good health throughout the experiment. The DM content of the LMM supplements ranged from 907 to $927 \mathrm{~g} / \mathrm{kg}$. During the 10 -week supplementation interval the average LW gain of the heifers was $0.37 \mathrm{~kg}$ /day but there were no differences $(P>0.05)$ among treatments.

There were three rain events 6-8 weeks before the experiment commenced, which provided in total $108 \mathrm{~mm}$. During the experiment there was $33 \mathrm{~mm}$ in Week $4,34 \mathrm{~mm}$ in Week 5 , and $110 \mathrm{~mm}$ in Week 10 . Voluntary intake of the LMM supplement was decreased for 1-2 weeks following each of these rainfall events (Fig. 1). Despite these variations the linear regression between voluntary intake of supplement and week of the experiment indicated that there was, on average across all the supplements, an increase $(P<0.01)$ in the voluntary intake of supplement DM by $2.9($ s.e. $=1.09) \mathrm{g} / \mathrm{week}$ during the 10 weeks of the experiment. The repeated-measures ANOVA showed that there was no interaction $(P>0.05)$ 
between the week of supplementation and the proportion of cottonseed meal in the LMM supplement on the voluntary intake of supplement DM. On average over the experiment the voluntary intake of supplement DM and non-protein $\mathrm{N}$ was increased $(P<0.05)$ by $26 \%$, and of supplement total $\mathrm{N}$ by $45 \%(P<0.05)$, by the increase in cottonseed meal content of the LMM from nil to $320 \mathrm{~g} / \mathrm{kg}$ (Table 1). Thus, the increase in intake of supplement $\mathrm{N}$ as cottonseed meal replaced salt in the LMM was due more to the increase in voluntary intake of the supplement than to the increase in $\mathrm{N}$ concentration in the supplement. Voluntary intake of supplement DM and of total $\mathrm{N}$ increased linearly with increasing proportion of cottonseed meal in the supplement as follows:

$$
\begin{aligned}
\mathrm{Y}_{1}= & 40.0(\text { s.e. } 1.18)+0.0350(\text { s.e. } 0.00645) \mathrm{X} \\
& \left(n=12, P<0.001, R^{2}=0.72 \text {, r.s.d. }=2.65\right), \\
\mathrm{Y}_{2}= & 6.1(\text { s.e. } 0.197)+0.00889(\text { s.e. } 0.000107) \mathrm{X} \\
& \left(n=12, P<0.001, R^{2}=0.86 \text {, r.s.d. }=0.440\right),
\end{aligned}
$$

where $Y_{1}$ was the average voluntary intake of supplement DM ( $\mathrm{g} /$ head.day), $\mathrm{Y}_{2}$ was the average voluntary intake of supplement

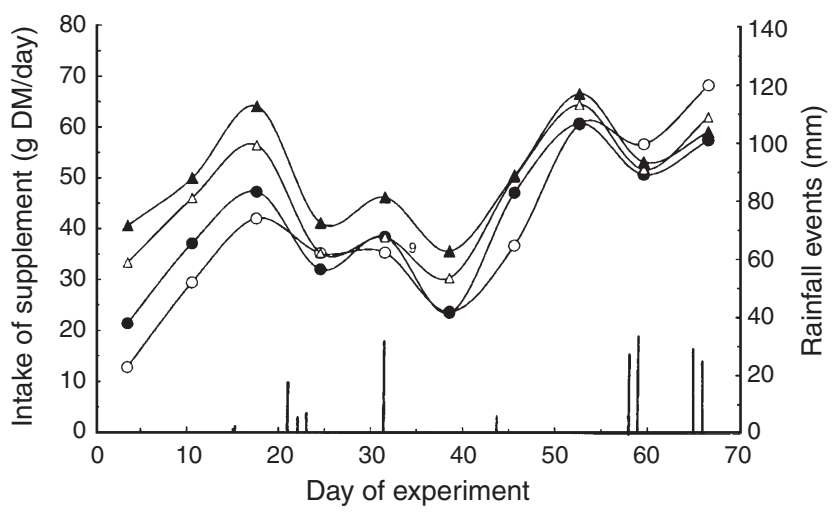

Fig. 1. Average voluntary intakes (g DM/head.day) in each week of loose mineral mix (LMM) supplements containing nil (LMM-1) (o), 80 (LMM-2) $(\bullet), 160($ LMM-3) $(\Delta)$ or $320(\mathrm{LMM}-4)(\mathbf{\Delta}) \mathrm{g}$ cottonseed meal $/ \mathrm{kg}$ of supplement. Supplements were offered to groups of heifers grazing late dry-season pasture. Bars indicate rainfall events during the experiment. total $\mathrm{N}$ (g/head.day), and $\mathrm{X}$ was the cottonseed meal content $(\mathrm{g} / \mathrm{kg})$ of the supplement.

Rain events on the days when lithium-labelled supplement were fed during Weeks 5 and 10 caused difficulties with measurement of the distribution of intake of the supplements by individual heifers. On the measurement day during Week 5 the lithium-labelled supplements were offered at 0700 hours, and rain (total $34 \mathrm{~mm}$ ) commenced at 1300 hours. As observations indicated that the heifers would not have consumed any supplement after the rain commenced, the heifers had only $6 \mathrm{~h}$ rather than the planned $9 \mathrm{~h}$ to ingest the lithium-labelled LMM. The amount of lithium-labelled supplement consumed was, on average across paddocks, $58 \%$ of that consumed during the previous 3 days. Similar difficulties occurred when lithium-labelled LMM supplements were offered during Week 10. There was $31 \mathrm{~mm}$ rain on the day before the lithium-labelled supplements were offered. The lithium-labelled supplements were again offered at 0700 hours, but rain (total $27 \mathrm{~mm}$ ) commenced at 1220 hours so that intake of the lithium-labelled supplement was lower than during the preceding days.

The distribution of voluntary intake of lithium-labelled supplement, measured as the $\mathrm{CV}$ within paddock groups, did not differ among treatments $(P>0.05)$; the $\mathrm{CV}$ averaged $96 \%$ in Week 5 and $97 \%$ in Week 10 (Table 1). The proportion of non-consumer heifers was not affected $(P>0.05)$ by the increasing proportion of cottonseed meal in the LMM, and averaged $19 \%$ in Week 5 and $15 \%$ in Week 10 . No relationships $(P>0.05)$ were observed between either the $\mathrm{CV}$ of supplement intake, nor the proportion of non-consumers of supplement, with the voluntary intake of supplement.

\section{Discussion}

Voluntary intake of supplements offered ad libitum to grazing cattle is, as for any component of the diet, likely to be a consequence of both innate factors (Heady 1964; Arnold et al. 1980) and conditioned responses in the animal (Provenza 1995, 1996; Arsenos and Kyriazakis 1999). The general attraction of cattle to consume cottonseed meal suggests that this feedstuff is innately attractive. Thus, it may be thought that in the present

Table 1. Voluntary intakes over 10 weeks of $\mathrm{DM}$ and total nitrogen $(\mathrm{N})$ (g/heifer.day) of four types of loose mineral mix (LMM) supplement where up to $320 \mathrm{~g} / \mathrm{kg}$ of salt in the LMM was replaced by the equivalent weight of cottonseed meal In addition the coefficient of variation $(\mathrm{CV} \%)$ of intake of lithium-labelled supplement among individual heifers within paddock groups, and the percent of heifers in paddock groups which did not consume any supplement (non-consumers) when lithiumlabelled LMM supplements were offered on 1 day during Week 5 and Week 10 are given. Means within each row followed by the same letter are not significantly different at $P=0.05$. s.e.d., standard error of the difference; $P$, probability; n.s, not significant; **, $P<0.01 ; * * *, P<0.001$

\begin{tabular}{llcccccc}
\hline Measurement & & \multicolumn{3}{c}{ Cottonseed meal in LMM (g/kg) } & s.e.d. & $P$ \\
& & 0 & 80 & 160 & 320 & & \\
\hline Supplement intake (g DM/day) & & $40.2 \mathrm{a}$ & $41.7 \mathrm{a}$ & $46.9 \mathrm{~b}$ & $50.8 \mathrm{~b}$ & 2.24 & $* *$ \\
Supplement intake (g N/day) & & $6.14 \mathrm{a}$ & $6.59 \mathrm{a}$ & $7.68 \mathrm{~b}$ & $8.88 \mathrm{c}$ & 0.377 & $* * *$ \\
Variability of supplement intake (CV\%) & Week 5 & 82 & 135 & 87 & 78 & 49 & n.s. \\
& Week 10 & 87 & 110 & 96 & 95 & 26 & n.s. \\
Non-consumers of supplement (\%) & Week 5 & 17 & 30 & 12 & 17 & 20 & n.s. \\
& Week 10 & 10 & 23 & 13 & 13 & 15 & n.s. \\
\hline
\end{tabular}


study the heifers increased their voluntary intake of the LMM supplements simply as a consequence of the relative changes in the proportions of the palatable (cottonseed meal) and the unpalatable (urea and ammonium sulfate) components of the LMM supplements. However, there is considerable evidence that the reduction in voluntary intake often observed when urea is included in a diet is associated primarily with the development of conditioned feed aversions to an excess of absorbed ammonia derived from the urea rather than to the taste of urea (Wilson et al. 1975; Chalupa et al. 1979; Kyriazakis and Oldham 1993). Such a conditioned feed aversion to LMM or molasses-urea supplements containing non-protein $\mathrm{N}$ has apparently developed in previous studies with similar heifers (Dixon et al. 2003b; Dixon 2013). Furthermore, sheep consuming low protein diets will acquire a conditioned feed preference to low amounts, and a conditioned feed aversion to high amounts, of urea or casein (Villalba and Provenza 1997; Arsenos and Kyriazakis 1999). Thus, LMM supplements containing high concentrations of non-protein $\mathrm{N}$ can be expected to cause either a conditioned feed preference or a conditioned feed aversion depending on the supply of rumen-degradable $\mathrm{N}$ from both pasture and supplement relative to fermentable metabolisable energy intake. It appears likely that in the present study both innate attraction to cottonseed meal and conditioned preferences for non-protein $\mathrm{N}$ in the LMM supplements influenced the voluntary intakes of the various LMM.

The high variation in the distribution among heifers of intakes of LMM supplements, and the substantial proportion of non-consumers of the LMM supplement on the day on which the lithium-labelled supplements were fed, observed in the present study are in agreement with previous reports of large variation among individuals and high proportions of nonconsumers in groups of cattle fed LMM (Dixon et al. 2000, 2001) or feed block supplements (Murray et al. 1978; Eggington et al. 1990; Dixon et al. 2003b). The procedure using lithiumlabelled supplements to estimate the distribution in supplement intake among animals in herds has been validated, including for circumstances similar to the present study where animals were blood sampled $\sim 24 \mathrm{~h}$ after ingestion of lithium-labelled supplements (Dixon et al. 2003a); larger errors may occur if there is a shorter interval between ingestion of the lithiumlabelled supplement and blood sampling (McLennan 1999). In addition, as the paddock groups of heifers in the present study were observed to behave as a single group, ingestion of the lithium-labelled supplement would have been over an interval much shorter than the $6 \mathrm{~h}$ during which the labelled supplement was offered. High variability appears to be unavoidable where voluntary intakes of supplement are comparable with the amounts consumed during the present experiment; it appears the variability can only be reduced with supplements associated with much higher voluntary intakes (Dixon et al. 2003b).

In conclusion, the experiment showed that inclusion of a palatable feedstuff such as cottonseed meal into LMM supplements increased the voluntary intake of this class of supplements by grazing cattle. The increase in voluntary intake of supplement $\mathrm{N}$ provided by the LMM was associated with both an increase in the concentration of $\mathrm{N}$ in the supplement and an increase in voluntary intake of supplement DM.

\section{Acknowledgements}

We thank Peter Fry, Adrian White and staff of the Swans Lagoon Research Station for assistance with the conduct of the experiment, and Hugh Mawhinney and Elroy McIlroy for the lithium analyses. The financial support of the former Meat Research Corporation (currently Meat and Livestock Australia) is gratefully acknowledged.

\section{References}

Arnold GW, de Boer ES, Boundy CAP (1980) The influence of odour and taste on the food preferences and food intake of sheep. Australian Journal of Agricultural Research 31, 571-587. doi:10.1071/AR9800571

Arsenos G, Kyriazakis I (1999) The continuum between preferences and aversions for flavoured foods in sheep conditioned by administration of casein doses. Animal Science 68, 605-618.

Chalupa W, Baile CA, McLaughlin CL, Brand JG (1979) Effect of introduction of urea on feeding behavior of Holstein heifers. Journal of Dairy Science 62, 1278-1284. doi:10.3168/jds.S0022-0302(79) $83412-8$

Dixon RM (1998) Improving cost-effectiveness of supplementation systems for breeder herds in northern Australia. Final Report, Project DAQ098, Meat Research Corporation, Sydney.

Dixon RM (2013) Controlling voluntary intake of molasses-based supplements in grazing cattle. Animal Production Science 53, 217-225.

Dixon RM, Porch I, White A (2000) Variability in intake of loose mineral mix supplements by grazing heifers. Asian-Australasian Journal of Animal Sciences 13(Supplement July 2000 B), 228.

Dixon RM, Smith D, Porch I, Petherick JC (2001) Effects of experience of young cattle on their voluntary intake of supplements. Australian Journal of Experimental Agriculture 41, 581-592. doi:10.1071/ EA00172

Dixon RM, Smith D, Reid A (2003a) Lithium salts as a marker of intake of supplements by cattle. Australian Journal of Experimental Agriculture 43, 37-46. doi:10.1071/EA01155

Dixon RM, White A, Fry P, Petherick JC (2003b) Effects of supplement type and previous experience on variability in intake of supplements by heifers. Australian Journal of Agricultural Research 54, 529-540. doi:10.1071/AR02091

Eggington AR, McCosker TH, Graham CA (1990) Intake of lick block supplements by cattle grazing native monsoonal tallgrass pastures in the Northern Territory. Australian Rangeland Journal 12, 7-13. doi:10.1071/RJ9900007

Heady HF (1964) Palatability of herbage and animal preference. Journal of Range Management 17, 76-82. doi:10.2307/3895315

Kyriazakis I, Oldham JD (1993) Diet selection in sheep: the ability of growing lambs to select a diet that meets their crude protein (nitrogen x 6.25) requirements. British Journal of Nutrition 69, 617-629. doi:10.1079/BJN19930064

Little DA (1982) Utilization of minerals. In 'Nutritional limits to animal production from pastures'. (Ed. JB Hacker) pp. 259-283. (Commonwealth Agricultural Bureaux: Slough, UK)

McDowell LR (1996) Feeding minerals to cattle at pasture. Animal Feed Science and Technology 60, 247-271. doi:10.1016/0377-8401(96) 00983-2

McLennan SR (1999) New techniques for estimating supplement intake by grazing herbivores. In 'Nutritional ecology of herbivores. Satellite symposium: emerging techniques for studying the nutrition of free ranging herbivores'. (Eds H Dove, SW Coleman) (CD-ROM) (San Antonio, Texas)

Murray RM, Graham C, Round J, Bond J (1978) Intake and response to phosphorus supplements by range cattle. In 'Proceedings of the first international rangeland congress'. (Ed. DN Hyder) pp. 427-428. (Society of Rangeland Management: Denver, CO) 
National Research Council (1996) 'Nutrient requirements of beef cattle.' 7th edn. (National Academy Press: Washington, DC)

Pamp DE, Goodrich RD, Meiske JC (1976) A review of the practice of feeding minerals free choice. World Review of Animal Production 12, $13-18$.

Provenza FD (1995) Role of learning in food preferences of ruminants: Greenhalgh and Reid revisited. In 'Ruminant physiology: digestion, metabolism, growth and reproduction'. (Eds W von Engelhardt, S Leonhard-Marek, G Breves, D Giesecke) pp. 233-247. (Ferdinand Enke Verlag: Stuttgart, Germany)

Provenza FD (1996) Acquired aversions as the basis for varied diets of ruminants foraging on rangelands. Journal of Animal Science 74, 2010-2020.
Suharyono (1992) Estimation of dietary supplement intake in sheep using $\mathrm{LiCl}$ as a marker. PhD Thesis, The University of New England, Armidale.

Villalba JJ, Provenza FD (1997) Preference for flavoured foods by lambs conditioned with intraruminal administration of nitrogen. British Journal of Nutrition 78, 545-561. doi:10.1079/BJN19970174

Wilson G, Martz FA, Campbell JR, Becker BA (1975) Evaluation of factors responsible for reduced voluntary intake of urea diets for ruminants. Journal of Animal Science 41, 1431-1437.

Winks L (1984) Cattle growth in the dry tropics of Australia. Review number 45, Australian Meat Research Committee, Sydney. 